\title{
Predictive effect of five hepatitis B virus markers on re-vaccination time of hepatitis $B$ vaccine
}

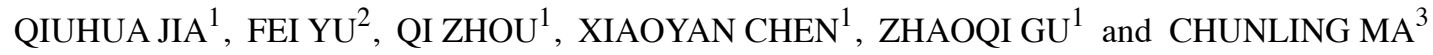 \\ ${ }^{1}$ Department of Medical Test, Women and Children's Health Care Hospital of Linyi; \\ ${ }^{2}$ Department of Clinical Laboratory, Affiliated Hospital of Shandong Medical College; ${ }^{3}$ Experimental Center \\ of Molecular Biology, Shandong Medical College, Linyi, Shandong 276000, P.R. China
}

Received September 27, 2018; Accepted April 23, 2020

DOI: $10.3892 /$ etm.2020.8859

\begin{abstract}
Examination of predictive effect of five hepatitis B virus (HBV) markers on the re-vaccination time of hepatitis $B$ vaccine was assessed. A total of 3,243 patients examined by five HBV markers in Women and Children's Health Care Hospital of Linyi from January 2015 to December 2017 were selected as the subjects and analyzed retrospectively. According to the previous time of hepatitis B antibody vaccination, subjects were divided into three groups: Shortterm group (previous time of hepatitis B vaccination $<5$ years, $\mathrm{n}=798$ ); medium-term group ( $>5$ years $-\leq 10$ years, $\mathrm{n}=1,242$ ); long-term group ( $>10$ years, $n=1,203)$. The enzyme linked immunosorbent assay was used to qualitatively analyze the five HBV markers, and chemiluminescence immunoassay was used to quantitatively analyze the five HBV markers. Hepatitis B surface antigen (HBsAg) in the long-term group and the medium-term group was significantly lower than that in the short-term group $(\mathrm{P}<0.001)$. HBsAg, hepatitis $\mathrm{B}$ e antigen, hepatitis B e antibody, hepatitis B core antibody in the long-term group was significantly higher than that in the medium-term and short-term group $(\mathrm{P}<0.050)$. The hepatitis B surface antibody in the long-term group was significantly lower than that in the other two groups $(\mathrm{P}<0.050)$. According to the previous time of the hepatitis $\mathrm{B}$ antibody vaccination, the patients in the long-term group were subdivided into three groups: Group A (vaccination time: $10-13$ years, $n=420)$; group $B(13-15$ years, $n=377)$ and group $\mathrm{C}(>15$ years, $\mathrm{n}=406)$. Geometric mean titer in group A was significantly lower than that in the other two groups $(\mathrm{P}<0.050)$. In conclusion, the protective effect of hepatitis $\mathrm{B}$ antibody vaccine is satisfactory for 10 years after vaccination, and re-vaccination is recommended after
\end{abstract}

Correspondence to: Dr Chunling Ma, Experimental Center of Molecular Biology, Shandong Medical College, 1 Jucai Six Road, Linyi, Shandong 276000, P.R. China

E-mail: ncs2pd@163.com; mach12003@163.com

Key words: five hepatitis B virus markers, hepatitis B vaccine, geometric mean titer, ELISA, chemiluminescence immunoassay more than 13 years of vaccination when the virus begins to increase significantly, in order to prevent the occurrence of hepatitis $\mathrm{B}$.

\section{Introduction}

Hepatitis B virus (HBV), also known as hepatitis B or second liver virus, is a very common infectious disease (1) with a wide transmission method and a high transmission speed, which can be transmitted through the blood and other body fluids of the patients. Hepatitis B, tuberculosis and acquired immune deficiency syndrome (AIDS) are known as the 'three major infectious diseases in the world' at present $(2,3)$. According to statistics, there are more than 400 million patients with hepatitis B worldwide, being 8 times that of AIDS (4). Hepatitis B infection has strong regional differences, the number of hepatitis B patients in Southeast Asia and Africa is significantly higher than that of other regions (5). According to the relevant statistics, there are more than 90 million patients in China and other populous countries (6). With the development and popularization of hepatitis B antibody vaccines, the infection rate of hepatitis $B$ has been effectively controlled, and its incidence is decreasing year by year (7). However, continuous studies have pointed out that the incidence of hepatitis B has begun to rise again this year, and the reasons are pointing to the effective duration of hepatitis B antibody vaccine (8-10). Hepatitis B antibody vaccine is one of the necessary vaccines in human body, but most patients have only been vaccinated at birth and neglected its importance in their subsequent life, which leads to the gradual disappearance of antibody vaccines after long-term metabolism in the body (11). Everyone is recommended to undergo a comprehensive physical examination at least once in three years to prevent all possible diseases (12). However, because the medical concept has not been popularized, most patients ignore their own health. Moreover, the incidence of hepatitis B has showed an upward trend recently, and there is no relevant research on the re-vaccination time of hepatitis $B$ antibody vaccine at present.

Examination of the five HBV markers [hepatitis B surface antigen (HBsAg), hepatitis B surface antibody (HBsAb), hepatitis Be antigen ( $\mathrm{HBeAg})$, hepatitis Be antibody ( $\mathrm{HBeAb})$, hepatitis $\mathrm{B}$ core antibody $(\mathrm{HBcAb})]$ is the most convenient and 
common method for detecting hepatitis B. However, there is still lack of research support to determine the effective duration of hepatitis B vaccine by the examination results. If the re-vaccination time of hepatitis $B$ vaccine can be predicted by examination of the five HBV markers, which is highly feasible, the clinical screening rate can be effectively improved and the occurrence of hepatitis B can also be reduced. Therefore, the hepatitis B antibodies of patients who underwent examination of the five HBV markers in recent years were quantitatively analyzed in this study to explore the optimal protective time and re-vaccination time of hepatitis B antibody vaccine for human body, and to provide reference and guidance for clinical practice.

\section{Patients and methods}

General information. A total of 3,243 patients examined by five HBV markers in Women and Children's Health Care Hospital of Linyi (Linyi, China) from January 2015 to December 2017 were selected as the research subjects and analyzed retrospectively, including 1,782 males and 1,461 females with an age range of 16-97 years and an average age of $26.83 \pm 42.37$ years.

The study was approved by the Ethics Committee of the Women and Children's Health Care Hospital of Linyi. Signed informed consents were obtained from the patients and/or guardians.

Inclusion and exclusion criteria. Inclusion criteria: Patients examined by five HBV markers in Women and Children's Health Care Hospital of Linyi; patients with complete case data; patients with hepatitis B vaccination history before examination. Exclusion criteria: Patients with liver neoplasms; patients with liver cirrhosis or fatty liver; patients with cirrhosis and fatty liver; patients smoking or with alcohol consumption within $24 \mathrm{~h}$ before the examination; patients undergoing liver surgery; severe ICU patients.

Methods. The time interval from the previous hepatitis B vaccination was 3 to 16 years, and the average distance from the inoculation was $5.42 \pm 2.97$ years, therefore the average of 5 years was taken as the basis of grouping. According to the previous time of the hepatitis B antibody vaccination, subjects were divided into three groups: Short-term group $(<5$ years, $\mathrm{n}=798)$; medium-term group ( $>5$ years $-\leq 10$ years, $n=1,242)$; long-term group ( $>10$ years, $\mathrm{n}=1,203)$. Examination of the five HBV markers was carried out by the laboratory of Women and Children's Health Care Hospital of Linyi. Fasting venous blood $(4 \mathrm{ml})$ was extracted, placed at room temperature for $30 \mathrm{~min}$, then centrifuged at $50 \mathrm{x} \mathrm{g}$ at $4^{\circ} \mathrm{C}$ for $10 \mathrm{~min}$ to obtain the upper serum. Qualitative analysis of five HBV markers was conducted by the enzyme-linked immunosorbent assay (ELISA) (Shanghai Yiji Industries Co., Ltd., DA6471044) in strict accordance with the instructions of the kit. If the results were false positive, repeated experiments were carried out to determine the accuracy. Quantitative analysis of five HBV markers was conducted by chemiluminescence immunoassay (CLIA) after the completion of qualitative analysis with MAGICL6800 automatic chemiluminescence determinator (Getein Biotechnology Co., Ltd).
Observation indicators. Qualitative and quantitative detection results of five HBV markers in three groups of patients. Qualitative results: HBsAg-positive indicates the presence of HBV. HBsAb-positive indicates successful vaccination of hepatitis B vaccine and the existence of hepatitis B antibody. $\mathrm{HBe} A g$-positive indicates that $\mathrm{HBV}$ replicates actively in human body, and the blood is poisonous and highly infectious. $\mathrm{HBeAb}$-positive indicates that replication of $\mathrm{HBV}$ has changed from active to relatively static. $\mathrm{HBcAb}$-positive indicates that the patient has been or is infected with HBV. The most seriously infected patients in the three groups were selected for a more in-depth geometric mean titer (GMT) analysis: The ability of antibodies to neutralize antigens such as viruses or toxins, the greater the numerical results, the stronger the ability of viruses or toxins. MGT is widely used to evaluate the concentration of viruses in the blood (13). Anti-HBs were detected by solid phase radioimmunoassay.

Statistical analysis. The data were analyzed and processed by the SPSS24.0 (IBM Corp); the quantitative data such as quantitative results of hepatitis B five markers were expressed as mean \pm standard deviation (SD), one-way ANOVA followed by LSD test was used for comparison between multiple groups; counting data such as $\mathrm{HBsAg}$ positive rates were expressed as rate, and Chi-square test was used for comparison between groups. $\mathrm{P}<0.050$ represents a statistically significant difference.

\section{Results}

Clinical data comparison. There was no significant difference in age, body weight, body mass index, sex, marital status, smoking and drinking habit between the three groups ( $P>0.050)$, which indicated that there was a comparability between the patients in the three groups (Table I).

Qualitative results of five $H B V$ markers. Comparison of the qualitative examination results of five HBV markers in the three groups showed that there were significant differences in each examination $(\mathrm{P}<0.001)$. The HBsAg in the long-term and the medium-term group showed no significant difference $(\mathrm{P}>0.001)$, but was significantly lower than that in the short-term group $(\mathrm{P}<0.050)$. The results of $\mathrm{HBsAb}$, $\mathrm{HBeAg}, \mathrm{HBeAb}, \mathrm{HBcAb}$ detection showed that there was no significant difference between short-term and medium-term group $(\mathrm{P}>0.050)$, while the long-term group was lower than the other two groups $(\mathrm{P}<0.001)$ (Table II). After examination, 14 patients with $\mathrm{HBsAg}(+), \mathrm{HBeAg}(+)$ and $\mathrm{HBcAb}(+)$ in the long-term group, showed fatigue, dizziness, loss of appetite, nausea, insomnia and occasionally suffered from distended pain, blunt pain or stabbing pain in the right upper abdomen or right back. Alanine aminotransferase, aspartate aminotransferase and total bilirubin levels in liver function examination were higher than those in normal controls, among which 3 cases were suspected to be compensated cirrhosis.

Quantitative results of five $H B V$ markers. The quantitative results of $\mathrm{HBsAg}, \mathrm{HBsAb}, \mathrm{HBeAg}, \mathrm{HBeAb}, \mathrm{HBcAb}$ in the short-term group were as follows: $0.12 \pm 0.03 \mathrm{ng} / \mathrm{ml}$, $332.51 \pm 45.68 \mathrm{mIU} / \mathrm{ml}, 0.07 \pm 0.08 \mathrm{PEIU} / \mathrm{ml}, 0.10 \pm 0.05 \mathrm{PEIU} / \mathrm{ml}$, 
Table I. Clinical data comparison [mean $\pm \mathrm{SD}, \mathrm{n}(\%)]$.

\begin{tabular}{|c|c|c|c|c|c|}
\hline Variables & $\begin{array}{c}\text { Short-term } \\
\text { group }(n=798)\end{array}$ & $\begin{array}{c}\text { Medium-term } \\
\text { group }(n=1,242)\end{array}$ & $\begin{array}{l}\text { Long-term group } \\
\qquad(\mathrm{n}=1,203)\end{array}$ & F value or $\chi^{2}$ & P-value \\
\hline \multirow[t]{2}{*}{ Age (years) } & & & & 2.519 & 0.081 \\
\hline & $33.67 \pm 29.48$ & $34.68 \pm 31.55$ & $36.81 \pm 35.26$ & & \\
\hline \multirow[t]{2}{*}{ Body weight (kg) } & & & & 0.294 & 0.745 \\
\hline & $64.92 \pm 20.36$ & $65.16 \pm 19.77$ & $64.53 \pm 21.14$ & & \\
\hline \multirow[t]{2}{*}{ BMI } & & & & 1.814 & 0.163 \\
\hline & $27.37 \pm 5.94$ & $27.15 \pm 6.08$ & $26.86 \pm 5.95$ & & \\
\hline Sex & & & & 0.346 & 0.841 \\
\hline Male & $442(55.39)$ & $687(55.31)$ & $653(54.28)$ & & \\
\hline Female & $356(44.61)$ & 555 (44.69) & $550(45.72)$ & & \\
\hline Residency & & & & 0.865 & 0.649 \\
\hline Urban & $712(89.22)$ & $1,123(90.42)$ & $1,086(90.27)$ & & \\
\hline Rural & $86(10.78)$ & $119(9.58)$ & 117 (9.73) & & \\
\hline Smoking & & & & 0.364 & 0.834 \\
\hline Yes & $468(58.65)$ & $712(57.33)$ & $693(57.61)$ & & \\
\hline No & $330(41.35)$ & $530(42.67)$ & $510(42.39)$ & & \\
\hline Drinking & & & & 0.052 & 0.974 \\
\hline Yes & $318(39.85)$ & $497(40.02)$ & $476(39.57)$ & & \\
\hline No & $480(60.15)$ & 745 (59.98) & $727(60.43)$ & & \\
\hline
\end{tabular}

BMI, body mass index.

Table II. Qualitative results of hepatitis B virus markers [n (\%)].

\begin{tabular}{|c|c|c|c|c|c|}
\hline Markers & $\begin{array}{c}\text { Short-term } \\
\text { group }(n=798)\end{array}$ & $\begin{array}{l}\text { Medium-term } \\
\text { group }(n=1,242)\end{array}$ & $\begin{array}{c}\text { Long-term } \\
\text { group }(n=1,203)\end{array}$ & $\chi^{2}$ & P-value \\
\hline HBsAg & & & & 46.34 & $<0.001$ \\
\hline+ & $\begin{array}{c}22(2.76) \\
776(97.24)\end{array}$ & $\begin{array}{c}117(9.42) \\
1,125(90.58)^{\mathrm{a}}\end{array}$ & $\begin{array}{c}134(11.14) \\
1,069(88.86)^{\mathrm{a}}\end{array}$ & & \\
\hline $\begin{array}{l}\mathrm{HBsAb} \\
+ \\
-\end{array}$ & $\begin{array}{c}784(98.25) \\
14(1.75)\end{array}$ & $\begin{array}{c}1,207(97.18) \\
35(2.82)\end{array}$ & $\begin{array}{r}1,114(92.60) \\
89(7.40)^{\mathrm{a}, \mathrm{b}}\end{array}$ & 66.692 & $<0.001$ \\
\hline $\begin{array}{l}\text { HBeAg } \\
+ \\
-\end{array}$ & $\begin{array}{c}0(0.00) \\
798(100.00)\end{array}$ & $\begin{array}{c}5(0.40) \\
1,237(99.60)\end{array}$ & $\begin{aligned} & 29(2.41) \\
& 1,174(97.59)^{\mathrm{a}, \mathrm{b}}\end{aligned}$ & 34.973 & $<0.001$ \\
\hline $\begin{array}{l}\mathrm{HBeAb} \\
+ \\
-\end{array}$ & $\begin{array}{c}3(0.38) \\
795(99.62)\end{array}$ & $\begin{array}{c}10(0.81) \\
1,232(99.19)\end{array}$ & $\begin{array}{c}40(3.33) \\
1,163(96.67)^{\mathrm{a}, \mathrm{b}}\end{array}$ & 34.563 & $<0.001$ \\
\hline $\begin{array}{l}\mathrm{HBcAb} \\
+ \\
-\end{array}$ & $\begin{array}{c}791(99.12) \\
7(0.88)\end{array}$ & $\begin{array}{c}1,224(98.55) \\
18(1.45)\end{array}$ & $\begin{array}{l}1,134(94.26) \\
69(5.74)^{\mathrm{a}, \mathrm{b}}\end{array}$ & 55.263 & $<0.001$ \\
\hline
\end{tabular}

${ }^{a} \mathrm{P}<0.050$, compared with the results of each examination in the short-term group; ${ }^{\mathrm{b}} \mathrm{P}<0.050$, compared with the results of each examination in the medium-term group. HBsAg, hepatitis B surface antigen; HBsAb, hepatitis B surface antibody; HBeAg, hepatitis B e antigen; HBeAb, hepatitis B e antibody; HBcAb, hepatitis B core antibody.

and $0.29 \pm 0.16 \mathrm{PEIU} / \mathrm{ml}$, respectively. Those in the mediumterm group were $0.28 \pm 0.17 \mathrm{ng} / \mathrm{ml}, 264.62 \pm 37.88 \mathrm{mIU} / \mathrm{ml}$, $0.26 \pm 0.10 \mathrm{PEIU} / \mathrm{ml}, 0.15 \pm 0.02 \mathrm{PEIU} / \mathrm{ml}, 0.57 \pm 0.10 \mathrm{PEIU} / \mathrm{ml}$, respectively, and those in the long-term group were $0.48 \pm 0.26$ $\mathrm{ng} / \mathrm{ml}, 153.67 \pm 58.69 \mathrm{mIU} / \mathrm{ml}, 0.39 \pm 0.17 \mathrm{PEIU} / \mathrm{ml}$, $0.17 \pm 0.14 \mathrm{PEIU} / \mathrm{ml}, 0.82 \pm 0.27 \mathrm{PEIU} / \mathrm{ml}$, respectively. There 

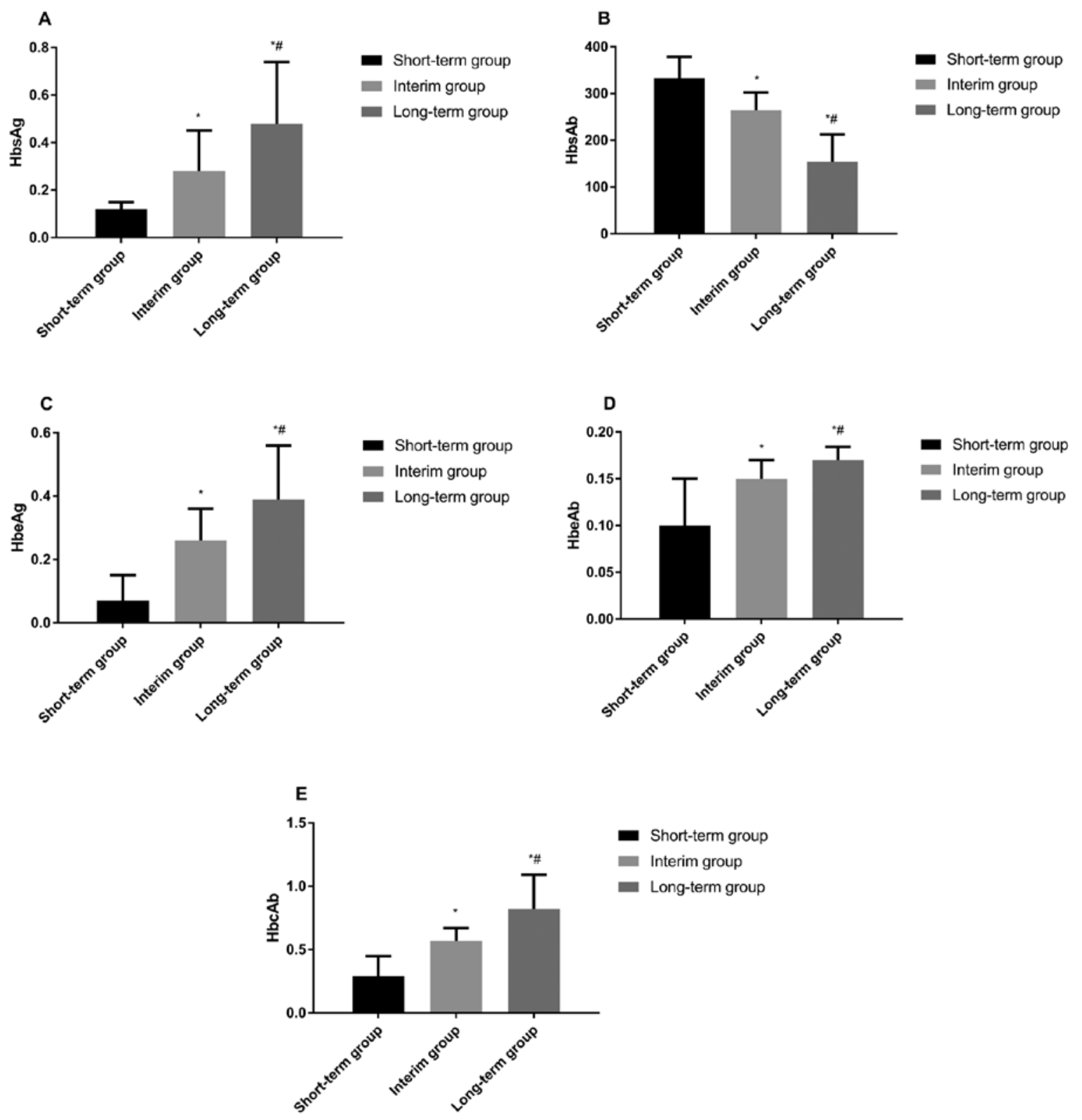

Figure 1. Quantitative results of five HBV markers. (A) Quantitative results of HBsAg in patients of the three groups. The HBsAg in long-term group was significantly higher than that in medium-term and short-term group, and that in medium-term group was significantly higher than that in short-term group. ${ }^{*} \mathrm{P}<0.050$, compared with the quantitative detection results of $\mathrm{HBs} \mathrm{Ag}$ in short-term group; ${ }^{*} \mathrm{P}<0.050$, compared with the quantitative detection results of $\mathrm{HBs} \mathrm{Ag}$ in medium-term group. (B) Quantitative results of HBsAb in patients of the three groups. The HBsAb in long-term group was significantly higher than that in medium-term and short-term group, and that in medium-term group was significantly higher than that in short-term group. ${ }^{*} \mathrm{P}<0.050$, compared with the quantitative detection results of HBsAb in short-term group; ${ }^{\#} \mathrm{P}<0.050$, compared with the quantitative detection results of HBsAb in medium-term group. (C) Quantitative results of HBeAg in patients of the three groups. The HBeAg in long-term group was significantly higher than that in medium-term and short-term group, and that in medium-term group was significantly higher than that in short-term group. ${ }^{*} \mathrm{P}<0.050$, compared with the quantitative detection results of $\mathrm{HBeAg}$ in short-term group; ${ }^{~} \mathrm{P}<0.050$, compared with the quantitative detection results of HBeAg in medium-term group. (D) Quantitative results of $\mathrm{HBeAb}$ in patients of the three groups. The HBeAb in long-term group was significantly higher than that in medium-term and short-term group, and that in medium-term group was significantly higher than that in short-term group. ${ }^{*} \mathrm{P}<0.050$, compared with the quantitative detection results of HBeAb in short-term group; ${ }^{~} \mathrm{P}<0.050$, compared with the quantitative detection results of $\mathrm{HBeAb}$ in medium-term group. (E) Quantitative results of $\mathrm{HBcAb}$ in patients of the three groups. The HBcAb in long-term group was significantly higher than that in medium-term and short-term group, and that in medium-term group was significantly higher than that in short-term group. ${ }^{*} \mathrm{P}<0.050$, compared with the quantitative detection results of $\mathrm{HBcAb}$ in short-term group; $\mathrm{P}<0.050$, compared with the quantitative detection results of $\mathrm{HBcAb}$ in medium-term group. HBV, hepatitis B virus; HBsAg, hepatitis B surface antigen; HBsAb, hepatitis B surface antibody; $\mathrm{HBeAg}$, hepatitis $\mathrm{Be}$ antigen; $\mathrm{HBeAb}$, hepatitis Be antibody; $\mathrm{HBcAb}$, hepatitis B core antibody.

were statistical differences in the quantitative results of each indicator between the three groups $(\mathrm{P}<0.050)$. $\mathrm{HBsAg}, \mathrm{HBeAg}$, $\mathrm{HBe} \mathrm{Ab}, \mathrm{HBcAb}$ in the long-term group were significantly higher than those in the other two groups, while those in the medium-term group were higher than those in the short-term group $(\mathrm{P}<0.050)$. The HBsAb in the long-term group was significantly lower than that in the other two groups, and that in the medium-term group was lower than that in the shortterm group $(\mathrm{P}<0.050)$ (Fig. 1).

GMT experiment. The results of qualitative and quantitative analysis of hepatitis B five markers showed that, among the 


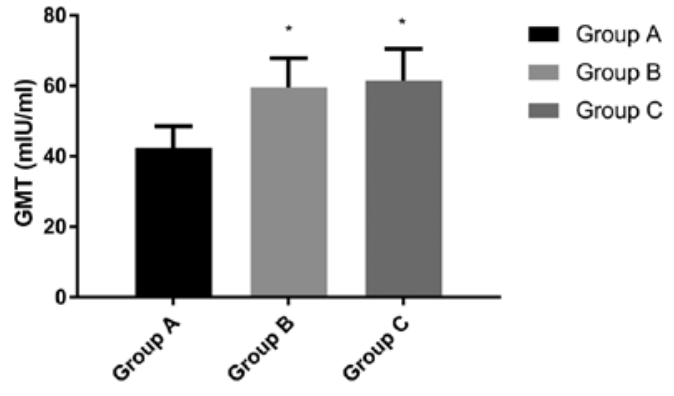

Figure 2. GMT results in patients of the three groups. There was no significant difference in GMT between long-term and medium-term group $(\mathrm{P}<0.050)$, but GMT in short-term group was significantly lower than that in other two groups $(\mathrm{P}<0.050)$. $\mathrm{P}<0.050$, compared with the GMT quantitative detection results in short-term group. GMT, geometric mean titer.

three groups, the results of the long-term group were the worst, so the patients in this group were selected for further analysis. According to the previous time of the hepatitis B antibody vaccination, the patients in the long-term group were subdivided into three groups: Group A (previous vaccination time: $10-13$ years, $n=420$ ); group $B$ (previous vaccination time: $13-15$ years, $n=377$ ); group $C$ (last vaccination time $>15$ years, $\mathrm{n}=406$ ). Results of GMT showed that GMT in group A was $42.37 \pm 6.14 \mathrm{mIU} / \mathrm{ml}$, that in group B was $59.63 \pm 8.24 \mathrm{mIU} / \mathrm{ml}$, and that in group $\mathrm{C}$ was $61.51 \pm 8.97 \mathrm{mIU} / \mathrm{ml}$. There was no significant difference in GMT between groups B and C $(\mathrm{P}<0.050)$, but GMT in group A was significantly lower than that in the other two groups $(\mathrm{P}<0.050)$ (Fig. 2).

\section{Discussion}

Hepatitis B, one of the most common infectious diseases in clinical practice, is highly infectious, and because of its slow onset and insignificant specific signs, most patients not only suffer from the disease, but also greatly increase the probability of disease transmission $(14,15)$. HBV can cause a series of immune responses after invading the body, the most severe of which is the change of hepatocytes (16). Moreover, it can also kill hepatitis B cells and cause hepatocyte inflammation, fibrosis and necrosis. Serious dysfunction of hepatic metabolic circulation directly leads to yellow urine, jaundice, fatigue, abnormal digestive tract, and even death directly in severe cases (17-19). At present, the incidence of hepatitis B is mainly divided into acute and chronic. About $90 \%$ of patients with acute hepatitis B can recover by themselves, but need isolation treatment $(20,21)$. However, there is no significant treatment for chronic hepatitis $B$, which can only be limited by long time antibiotics use (3-5 years or more) $(22,23)$. At present, chronic hepatitis B accounts for the vast majority in clinic (24). Therefore, in order to reduce the harm of hepatitis B to human body, the most effective method is to vaccinate hepatitis B antibody in time. Since there is no reference study at present to point out how long the best period of hepatitis B vaccination is, this study, through experimental analysis and taking hepatitis B five markers as research direction, analyzed the re-vaccination time of hepatitis B vaccine in order to provide reference and guidance for clinical diagnosis and treatment of hepatitis B.
Examination of five HBV markers is the most effective detection method for hepatitis B in clinical practice. HBsAgpositive represents the existence of complete HBV particles in the patient's body; HBsAb-positive represents the existence of immune and protective antibodies against HBV in the patient's body; $\mathrm{HBeAg}$ is an antigen within $\mathrm{HBV}$, and its positive expression indicates the activation of $\mathrm{HBV}$ in patients; $\mathrm{HBeAb}$-positive means that HBV is already in a stable or rehabilitative stage; and as a marker of hepatitis B infection, the positive expression of $\mathrm{HBcAb}$ indicates that the patient has or has had hepatitis B (25). In the qualitative results of this study, there was no significant difference between the medium-term and the long-term groups of HBsAb-positive patients, which were significantly more than the short-term group, suggesting that there were significantly more patients with hepatitis B virus in the medium-term and long-term groups than in the short-term group. The likelihood of $\mathrm{HBV}$ infection in patients after more than 5 years after vaccination with hepatitis B began to increase significantly. There were no significant differences between the short-term group and the medium-term group of HBsAb-positive patients, which were significantly more than the long-term group, suggesting that there was a relatively stable hepatitis B resistance in the body within 10 years after vaccination. After 10 years, hepatitis B antibodies gradually disappeared, and the risk of contracting hepatitis B began to increase significantly. The comparison of the positive cases of $\mathrm{HBeAg}$ in the three groups further confirmed our hypothesis. None of the patients in the short-term group were HBeAg-positive, while there were only $0.40 \% \mathrm{HBeAg}$-positive cases in the medium-term group and $2.41 \% \mathrm{HBeAg}$-positive cases in the long-term group. This also suggests that after 5 years of hepatitis B vaccination, hepatitis B patients will begin to appear, and the infection rate will increase significantly after 10 years of vaccination. The comparison of $\mathrm{HBeAb}$ and $\mathrm{HBcAb}$ in the three groups showed that the longterm group had the most HBeAb and HBcAb positive patients, which further proves that patients are at their worst after 10 years of hepatitis B vaccination. In summary, the qualitative analysis of five hepatitis B showed that patients who had been vaccinated with hepatitis $B$ vaccine for more than 10 years began to experience a significant decrease in the ability of the hepatitis B antibody vaccine to work in the body, and a significant increase in the risk of hepatitis B infection. The results of the quantitative analysis are also consistent with the results of the above examination, and can verify our experimental results. GMT, as an excellent indicator for evaluating the concentration of virus in the blood, is currently widely used in clinical practice to detect viral infections in patients (26-28). The greater the test results, the stronger the ability to represent viruses or toxins. The study by Folaranmi et al (29) found the recommendation of the vaccination time of the meningococcal vaccine of type $\mathrm{B}$ by GMT, and Benoit et al (30) confirmed that GMT was closely related to the viral infection of seasonal influenza. In order to determine the exact time of antibody decline after vaccination with hepatitis B vaccine, we performed a GMT test on patients in the long-term group. The results showed that patients with vaccination over 13 years have significantly higher GMT than patients with less than 13 years. It is suggested that the resistance of hepatitis B antibody vaccine begins to decrease significantly after 13 years, and patients should be revaccinated 13 years after hepatitis B vaccination. 
Examination of the five HBV markers is very sensitive to the situation of hepatitis B infection, but it is easily affected by external environmental factors in the process of detection. Yang et al (31) pointed out that hemolysis, blood vessel pollution, incomplete washing, fibrinogen and other factors might cause differences in the results of five HBV markers examination. In this study, inspectors were all senior examiners at the director level in the hospital, and factors that might affect the outcome were avoided as much as possible to further enhance the accuracy of the experimental results. The results of this study show that the protective ability of hepatitis B antibody vaccine begins to decrease 10 years after vaccination, and its mechanism needs to be further studied.

The determination of re-vaccination time of hepatitis B antibody vaccine by five HBV markers was analyzed in this experiment. However, due to the limited experimental conditions, there were still some shortcomings. The subjects were of relatively similar origin, not excluding the possibility that there might be differences in the results of examination among different ethnic groups. Other human or environmental factors were not excluded which might have an effect on the experimental results.

In conclusion, the protective effect of hepatitis B antibody vaccine is satisfactory within 10 years after vaccination, and re-vaccination is recommended after more than 13 years of vaccination when the virus begins to increase significantly, in order to prevent the occurrence of hepatitis B.

\section{Acknowledgements}

Not applicable.

\section{Funding}

No funding was received.

\section{Availability of data and materials}

The datasets used and/or analyzed during the present study are available from the corresponding author on reasonable request.

\section{Authors' contributions}

QJ and FY wrote the manuscript and performed ELISA. CM and QZ collected and analyzed the patients' general data. XC and $\mathrm{ZG}$ were responsible for the analysis of the observation indicators. All authors read and approved the final version of the manuscript.

\section{Ethics approval and consent to participate}

The study was approved by the Ethics Committee of Women and Children's Health Care Hospital of Linyi (Linyi, China). Signed informed consents were obtained from the patients and/or guardians.

\section{Patient consent for publication}

Not applicable.

\section{Competing interests}

The authors declare that they have no competing interests.

\section{References}

1. Sarin SK, Kumar M, Lau GK, Abbas Z, Chan HL, Chen CJ, Chen DS, Chen HL, Chen PJ, Chien RN, et al: Asian-Pacific clinical practice guidelines on the management of hepatitis B: A 2015 update. Hepatol Int 10: 1-98, 2016.

2. Terrault NA, Bzowej NH, Chang KM, Hwang JP, Jonas MM and Murad MH; American Association for the Study of Liver Diseases: AASLD guidelines for treatment of chronic hepatitis B. Hepatology 63: 261-283, 2016.

3. Lok AS, McMahon BJ, Brown RS Jr, Wong JB, Ahmed AT, Farah W, Almasri J, Alahdab F, Benkhadra K, Mouchli MA, et al: Antiviral therapy for chronic hepatitis B viral infection in adults: A systematic review and meta-analysis. Hepatology 63: 284-306, 2016.

4. Wang C, Ji D, Chen J, Shao Q, Li B, Liu J, Wu V, Wong A, Wang Y, Zhang $\mathrm{X}$, et al: Hepatitis due to reactivation of hepatitis $\mathrm{B}$ virus in endemic areas among patients with hepatitis $\mathrm{C}$ treated with direct-acting antiviral agents. Clin Gastroenterol Hepatol 15: 132-136, 2017.

5. Brown RS Jr, McMahon BJ, Lok AS, Wong JB, Ahmed AT, Mouchli MA, Wang Z, Prokop LJ, Murad MH and Mohammed K: Antiviral therapy in chronic hepatitis B viral infection during pregnancy: A systematic review and meta-analysis. Hepatology 63: 319-333, 2016.

6. Ye B, Liu X, Li X, Kong H, Tian L and Chen Y: T-cell exhaustion in chronic hepatitis B infection: Current knowledge and clinical significance. Cell Death Dis 6: e1694, 2015.

7. Bruce MG, Bruden D, Hurlburt D, Zanis C, Thompson G, Rea L, Toomey M, Townshend-Bulson L, Rudolph K, Bulkow L, et al: Antibody levels and protection after hepatitis B vaccine: Results of a 30-year follow-up study and response to a booster dose. J Infect Dis 214: 16-22, 2016.

8. Hernán MA, Jick SS, Olek MJ and Jick H: Recombinant hepatitis B vaccine and the risk of multiple sclerosis: A prospective study. Neurology 63: 838-842, 2004.

9. Van Damme P: Long-term protection after hepatitis B vaccine. J Infect Dis 214: 1-3, 2016.

10. Qiu Y, Guo L, Zhang S, Xu B, Gao Y, Hu Y, Hou J, Bai B, Shen H and Mao P: DNA-based vaccination against hepatitis $B$ virus using dissolving microneedle arrays adjuvanted by cationic liposomes and CpG ODN. Drug Deliv 23: 2391-2398, 2016.

11. Nelson NP, Easterbrook PJ and McMahon BJ: Epidemiology of hepatitis B virus infection and impact of vaccination on disease. Clin Liver Dis 20: 607-628, 2016.

12. Guirguis-Blake JM, Senger CA, Webber EM, Mularski RA and Whitlock EP: Screening for chronic obstructive pulmonary disease: Evidence report and systematic review for the US preventive services task force. JAMA 315: 1378-1393, 2016.

13. Eichelberger MC, Couzens L, Gao Y, Levine M, Katz J, Wagner R, Thompson CI, Höschler K, Laurie K, Bai T, et al; ELLA study participants: Comparability of neuraminidase inhibition antibody titers measured by enzyme-linked lectin assay (ELLA) for the analysis of influenza vaccine immunogenicity. Vaccine 34: 458-465, 2016.

14. Lampertico P, Agarwal K, Berg T, Buti M, Janssen HLA, Papatheodoridis G, Zoulim F and Tacke F; European Association for the Study of the Liver. Electronic address: easloffice@ easloffice.eu; European Association for the Study of the Liver: EASL 2017 Clinical Practice Guidelines on the management of hepatitis B virus infection. J Hepatol 67: 370-398, 2017.

15. Kim WR, Berg T, Asselah T, Flisiak R, Fung S, Gordon SC, Janssen HL, Lampertico P, Lau D, Bornstein JD, et al: Evaluation of APRI and FIB-4 scoring systems for non-invasive assessment of hepatic fibrosis in chronic hepatitis B patients. J Hepatol 64: 773-780, 2016.

16. Buti M, Gane E, Seto WK, Chan HL, Chuang WL, Stepanova T, Hui AJ, Lim YS, Mehta R, Janssen HL, et al; GS-US-320-0108 Investigators: Tenofovir alafenamide versus tenofovir disoproxil fumarate for the treatment of patients with $\mathrm{HBeAg}$-negative chronic hepatitis B virus infection: A randomised, double-blind, phase 3, non-inferiority trial. Lancet Gastroenterol Hepatol 1: 196-206, 2016. 
17. Roberts H, Kruszon-Moran D, Ly KN, Hughes E, Iqbal K, Jiles RB and Holmberg SD: Prevalence of chronic hepatitis B virus (HBV) infection in U.S. households: National Health and Nutrition Examination Survey (NHANES), 1988-2012. Hepatology 63: 388-397, 2016.

18. Paul S, Saxena A, Terrin N, Viveiros K, Balk EM and Wong JB Hepatitis B virus reactivation and prophylaxis during solid tumor chemotherapy: A systematic review and meta-analysis. Ann Intern Med 164: 30-40, 2016.

19. Decorsière A, Mueller H, van Breugel PC, Abdul F, Gerossier L, Beran RK, Livingston CM, Niu C, Fletcher SP, Hantz O, et al: Hepatitis B virus X protein identifies the $S m c 5 / 6$ complex as a host restriction factor. Nature 531: 386-389, 2016.

20. Lok AS, Pan CQ, Han SH, Trinh HN, Fessel WJ, Rodell T, Massetto B, Lin L, Gaggar A, Subramanian GM, et al: Randomized phase II study of GS-4774 as a therapeutic vaccine in virally suppressed patients with chronic hepatitis B. J Hepatol 65: 509-516, 2016.

21. Harris AM, Iqbal K, Schillie S, Britton J, Kainer MA, Tressler S and Vellozzi C: Increases in acute hepatitis B virus infections Kentucky, Tennessee, and West Virginia, 2006-2013. MMWR Morb Mortal Wkly Rep 65: 47-50, 2016.

22. Park JJ, Wong DK, Wahed AS, Lee WM, Feld JJ, Terrault N, Khalili M, Sterling RK, Kowdley KV, Bzowej N, et al; Hepatitis B Research Network: Hepatitis B Virus-specific and global T-cell dysfunction in chronic hepatitis B. Gastroenterology 150 : 684-695.e5, 2016.

23. Takayama H, Sato T, Ikeda F and Fujiki S: Reactivation of hepatitis B virus during interferon-free therapy with daclatasvir and asunaprevir in patient with hepatitis $B$ virus/hepatitis $C$ virus co-infection. Hepatol Res 46: 489-491, 2016.

24. Hayashi K, Ishigami M, Ishizu Y, Kuzuya T, Honda $T$, Nishimura D, Goto H and Hirooka Y: A case of acute hepatitis B in a chronic hepatitis $\mathrm{C}$ patient after daclatasvir and asunaprevir combination therapy: Hepatitis B virus reactivation or acute self-limited hepatitis? Clin J Gastroenterol 9: 252-256, 2016.
25. Xiang KH, Michailidis E, Ding H, Peng YQ, Su MZ, Li Y, Liu XE, Dao Thi VL, Wu XF, Schneider WM, et al: Effects of amino acid substitutions in hepatitis $B$ virus surface protein on virion secretion, antigenicity, HBsAg and viral DNA. J Hepatol 66: 288-296, 2017.

26. Fries LF, Smith GE and Glenn GM: A recombinant viruslike particle influenza A (H7N9) vaccine. N Engl J Med 369: 2564-2566, 2013

27. Patel M, Glass RI, Jiang B, Santosham M, Lopman B and Parashar U: A systematic review of anti-rotavirus serum $\operatorname{IgA}$ antibody titer as a potential correlate of rotavirus vaccine efficacy. J Infect Dis 208: 284-294, 2013.

28. van Assen S, Holvast A, Telgt DSC, Benne CA, de Haan A, Westra J, Kallenberg CG and Bijl M: Patients with humoral primary immunodeficiency do not develop protective anti-influenza antibody titers after vaccination with trivalent subunit influenza vaccine. Clin Immunol 136: 228-235, 2010.

29. Folaranmi T, Rubin L, Martin SW, Patel M and MacNeil JR; Centers for Disease Control (CDC): Use of serogroup B meningococcal vaccines in persons aged $\geq 10$ years at increased risk for serogroup B meningococcal disease: Recommendations of the Advisory Committee on Immunization Practices, 2015. MMWR Morb Mortal Wkly Rep 64: 608-612,2015.

30. Benoit A, Beran J, Devaster JM, Esen M, Launay O, LerouxRoels G, McElhaney JE, Oostvogels L, van Esse GA and Gaglani M: Hemagglutination inhibition antibody titers as a correlate of protection against seasonal A/H3N2 influenza disease. Open Forum Infect Dis 2: ofv067. doi: 10.1093/ofid/ofv067. eCollection 2015 Apr.

31. Yang S, Tian G, Cui Y, Ding C, Deng M, Yu C, Xu K, Ren J, Yao J, Li Y, et al: Factors influencing immunologic response to hepatitis B vaccine in adults. Sci Rep 6: 27251, 2016. 